Article

\title{
Hydrogeochemical Behavior of Reclaimed Highly Reactive Tailings, Part 1: Characterization of Reclamation Materials
}

\author{
Alex Kalonji-Kabambi ${ }^{1, * \mathbb{D}}$, Bruno Bussière ${ }^{1,2}$ and Isabelle Demers ${ }^{1,3}$ \\ 1 UQAT-Polytechnique Research Institute on Mine and Environment, Rouyn-Noranda, QC J9X 5E4, Canada; \\ Bruno.Bussiere@uqat.ca (B.B.); Isabelle.Demers@uqat.ca (I.D.) \\ 2 NSERC-UQAT Industrial Chair on Mine Site Reclamation, Rouyn-Noranda, QC J9X 5E4, Canada \\ 3 Canada Research Chair on Integration of the Environment in the Mine Life Cycle, \\ Rouyn-Noranda, QC J9X 5E4, Canada \\ * Correspondence: alex.kalonji-kabambi@uqat.ca
}

Received: 28 April 2020; Accepted: 29 June 2020; Published: 30 June 2020

\begin{abstract}
The production of solid mine wastes is an integral part of the extraction and metallurgical processing of ores. The reclamation of highly reactive mine waste, with low neutralizing potential, is still a significant challenge for the mining industry, particularly when natural soils are not available close to the site. Some solid mine wastes present interesting hydro-geotechnical properties which can be taken advantage of, particularly for being used in reclamation covers to control acid mine drainage. The main objective of this research was to evaluate the use of mining materials (i.e., tailings and waste rock) in a cover with capillary barrier effects (CCBE) to prevent acid mine drainage (AMD) from highly reactive tailings. The first part of the project reproduced in this article involves context and laboratory validation of mining materials as suitable for a CCBE, while the companion paper reports laboratory and field results of cover systems made with mining materials. The main conclusions of the Part 1 of this study were that the materials studied (low sulfide tailings and waste rocks) had the appropriate geochemical and hydrogeological properties for use as cover materials in a CCBE. Results also showed that the cover mining materials are not acid-generating and that the LaRonde tailings are highly reactive with $\mathrm{pH}$ close to 2 , with high concentrations of metals and sulfates.
\end{abstract}

Keywords: acid mine drainage; cover with capillary barrier effects; mine wastes; reactive tailings; kinetic tests; laboratory column tests; field cell tests

\section{Introduction}

In recent decades, stricter regulations have forced the mining sector to better protect the environment both during and after operations. One important environmental issue of the mining sector is the generation of acid mine drainage (AMD) from mine wastes such as tailings and waste rocks [1-4]. In order to control AMD generation, most current reclamation methods seek to control one or more of the main components involved: atmospheric oxygen, sulfide minerals, and water [5-8]. In humid climates, oxygen barriers are recognized as the one of the most efficient approach to control the AMD generation [9] among which cover with capillary barrier effects (CCBE) made of multiple layers of soils or other geological materials is one of the preferred options. The three main CCBE layers are (from bottom to top): (1) the capillary break layer (CBL), which consists of a coarse-grained material that acts as a capillary break; (2) the moisture-retaining layer (MRL), which is made of a fine-grained material and is aimed at controlling fluid (gas and water) movement; and (3) the drainage layer (DL), which is made of a coarse-grained material, prevents evaporation, and favors water lateral drainage [10]. In a CCBE. the contrasting unsaturated hydrogeological properties of the cover materials [11-13] 
allows maintaining the MRL at a high degree of saturation $\left(\mathrm{S}_{w} ;\right.$ typically $\left.>85 \%\right)$. Since the diffusion of oxygen through water is low $\left(2.4 \times 10^{-9} \mathrm{~m}^{2} \mathrm{~s}^{-1}\right)$, this high $S_{\mathrm{w}}$ value limits oxygen diffusion to the reactive waste $[11,14-16]$.

The full-scale implementation of CCBEs at tailings storage facilities (TSF) requires a significant volume of natural materials $[17,18]$. Therefore, when the appropriate cover materials are not located within close proximity to a site, costs related to transportation can be prohibitive $[19,20]$. Furthermore. the stripping of undisturbed lands to extract cover materials for the CCBE can affect the capacity of mine operators to obtain the social acceptability. Consequently, many mining companies are increasingly becoming interested in valorizing mine wastes (e.g., tailings, waste rocks, and water treatment sludges) as materials for reclamation covers and other geoengineering applications. The reuse of mining materials can reduce waste management and reclamation costs as well as the environmental risks associated with mine waste storage facilities [21,22]. The effectiveness of CCBEs constructed from low-sulfide or desulfurized tailings has been demonstrated in prior laboratory studies [23,24], as well as in several case studies $[17,18,25,26]$. The possibility of using waste rocks as a material in the CBL and DL of a CCBE was also successfully assessed in the laboratory and by numerical modelling [27-30].

In the literature, many studies examined the efficiency of different types of covers to control and mitigate AMD generation, but few examined the reclamation of highly pyritic tailings with no or very low neutralizing capacity. The reclamation of such tailings is uncertain and has always been a considerable challenge. From the existing studies on reclamation of tailings rich in sulfides, one can find the study on turbulence driven metal release from suspended pyrrhotite tailings [31] conducted on Falconbridge Strathcona mine tailings (75\% pyrrhotite and 0.14\% chalcopyrite contents). Davé and Paktunc [32] assessed the surface reactivity of high-sulfide copper mine tailings under shallow water cover conditions. This study was performed on a copper mine tailings that had a sulfide content of $20 \%$, a negligible neutralization potential of approximately 0 to $2 \mathrm{~kg} \mathrm{CaCO}_{3} / \mathrm{t}$, and a negative net neutralization potential in the range of -600 to $-700 \mathrm{~kg} \mathrm{CaCO}_{3} / \mathrm{t}$. A laboratory study on pyritic tailings ( $80 \%$ pyrite content with very low neutralizing capacity) placed under a water cover for various hydrodynamic conditions was carried out by Awoh et al. [33]. The same material was studied in the field to assess their in situ chemical and physical stability [34]. Hence, most of the work on sulfide-rich tailings with low neutralizing potential focused on controlling their AMD generation using laboratory or field scale water cover. To the authors' knowledge, studies that focused on controlling AMD of a sulfide-rich tailings ( $\%$ sulfides $>30 \%$ ) with no or very low neutralizing capacity by a CCBE made entirely of low sulfide mine wastes are rare in the literature.

The main objective of this research was to study the hydrogeochemical behavior of highly reactive tailings protected by a CCBE made entirely of low sulfide mine wastes (i.e., tailings and waste rock). The work was performed using existing materials from two mines owned by Agnico Eagle Mine Ltd., the LaRonde and Goldex mines. Experiments in the laboratory were first conducted to characterize the physical, hydrogeological, geochemical, and mineralogical properties of the reactive tailings and the cover mine waste materials. The characterization of cover materials was conducted in order to verify if the available low sulfide tailings and waste rock had suitable properties for use in a CCBE, and to assess how reactive were the highly reactive LaRonde mine tailings. Secondly, using a large column test. the hydrogeochemical behavior of a CCBE made with mining materials and placed over acid-generating highly reactive tailings was evaluated. The large column was instrumented and monitored for 18 cycles (504 days). Then. the same laboratory CCBE configuration was tested in situ at an intermediate scale in a field experimental cell, in addition of a control cell. Field experimental cells (control and covered cells) were also instrumented and monitored for 3 years (2017-2019). Due to the size of the study, results are integrated into two distinct but complementary articles. The present article describes the context and the laboratory validation of the suitability of the tested mine waste materials to be used as CCBE layers, while the Part 2 of this study reports the main laboratory and field results related to the CCBE made with the tested mine wastes (characterized in the Part 1). The Part 2 of this study also analyzes and compares the hydrogeochemical results and oxygen flux 
obtained from the laboratory column and the field experimental cell exposed to real climatic conditions. The main originality of this study is related to the use of mining materials in a CCBE to reclaim highly reactive tailings. If the approach is demonstrated successful, it would allow to reduce the footprint of mine sites by limiting the use of natural soil, while controlling water contamination from the highly reactive tailings.

\section{Materials and Methods}

\subsection{Sampling Sites and Material Preparation}

Reactive tailings and the three cover materials used in the present study (low-sulfide tailings, non-acid-generating waste rocks, and potentially acid-generating waste rocks) were taken from different mines owned and operated by Agnico Eagles Mines Ltd. (AEM, Canada). The reactive tailings (TR) came from LaRonde mine, which produces copper and zinc concentrates by flotation and gold and silver by cyanidation and electrowinning. The LaRonde underground mining complex generates approximately 2.4 Mt of acid-generating tailings annually, which are disposed of in a 165 ha TSF. The TR were taken directly from the TSF, in a portion of the site where the tailings were not already oxidized. The low-sulfide tailings (TG) were taken from Goldex mine, which produces gold, gold-bearing pyrite concentrates, and desulfurized (i.e., low-sulfide) tailings. The non-acid-generating waste rocks (WL) and potentially acid-generating waste rocks (WP) were sampled at the LaRonde mine and sieved on-site to a maximum particle size of $50 \mathrm{~mm}$. This size fraction was selected because preliminary tests showed that similar waste rock fractions can act as efficient capillary break layers in CCBEs $[28,35,36]$. The reactive tailings and cover materials were transported to the laboratory for characterization. Samples of all materials were homogenized using a spade to avoid, as much as possible, heterogeneities in the chemical and mineralogical properties. The reactive tailings were submerged in water prior to the start of the tests. However, despite this precaution, at the beginning of the laboratory experiments the interstitial water was acidic $(\mathrm{pH}=1.87)$ and loaded with dissolved metals and sulfate (e.g., $\mathrm{Fe}=2.350 \mathrm{~g} / \mathrm{L}, \mathrm{Zn}=2.940 \mathrm{~g} / \mathrm{L}$, and $\mathrm{SO}_{4}=22.018 \mathrm{~g} / \mathrm{L}$ ).

\subsection{Physical, Hydrogeological, Chemical, and Mineralogical Characterizations}

The grain-size distributions (GSDs) of the TR and TG were determined using a Malvern Mastersizer laser particle size analyzer [37]. The GSD of the WL and WP were determined by mechanical sieving according to ASTM standard D422 [38] for particles larger than $425 \mu \mathrm{m}$ and using laser particle size analysis for finer grain sizes. The specific gravity $\left(G_{s}\right)$ of each material was determined by a helium pycnometer (Micromeritics AccuPyc 1330, Micrometrics Instrument Corporation, Norcross, GA, United States) according to ASTM standard D854-10 [39].

The saturated hydraulic conductivities $\left(\mathrm{k}_{\mathrm{sat}}\right)$ of the tailings samples were evaluated using a standard rigid-wall permeameter according to ASTM standard D5856 [40]. The $\mathrm{k}_{\text {sat }}$ of the waste rocks was measured using a constant head permeability test in a large high-density polyethylene (HDPE) column (0.80 $\mathrm{m}$ in height and $0.30 \mathrm{~m}$ in diameter) using the method proposed by Peregoedova et al. [41]. Water retention curves (WRCs) were determined for the tailings using a pressure cell (Tempe Cell) following ASTM D3152-72 [42]. Experimental data were fitted with the RETC software [43] to the van Genuchten model [44]. The waste rocks' WRCs were obtained through column drainage tests following the procedures proposed by Chapuis et al., Hernandez, and Peregoedova et al. [45-47]. In brief, this method involved first saturating a column of waste rocks, then draining it under atmospheric pressure. Waste rocks were removed from the column in 10-cm layers and their gravimetric water content was measured. Assuming hydrostatic equilibrium. the calculated volumetric water contents were plotted against elevation to obtain the WRC. Experimental data were also fitted with the RETC software.

The bulk chemical composition of all samples was determined by inductively coupled plasma atomic emission spectrometry (ICP-AES; Perkin Elmer Optima 3100 RL, PerkinElmer, Billerica, MA, United States) following a complete digestion with $\mathrm{HNO}_{3} / \mathrm{Br}_{2} / \mathrm{HF} / \mathrm{HCl}$. The mineralogy of the materials 
was obtained through X-ray diffraction (XRD) using the quantitative Rietveld refinement method implemented with TOPAS software v2.2 [48,49]. The detection limit of this method is approximately $\pm 1 \%$ [50]. The identification of minor phases was achieved using scanning electron microscopy (SEM) analyses [51]. Mineralogical reconciliation was performed using ICP-AES and XRD data to provide a better quantification of the mineralogical composition; details on this approach were presented by Bouzahzah [50]. The total sulfur and carbon contents of all materials were analyzed by infrared absorption after combustion in an induction furnace (Eltra CS-2000). The detection limit of these analyses was approximately $0.05 \%$ for $\mathrm{C}_{\text {total }}$ and $0.009 \%$ for $\mathrm{S}_{\text {total }}$. The acid potential (AP) was calculated from the total sulfur content $(\% \mathrm{~S} \times 31.3)$ and the neutralization potential $(\mathrm{NP})$ was calculated using the total carbon content $(\% \mathrm{C} \times 83.3)$ [52-54]. Oxidation-neutralization curves, which were first developed by Benzaazoua et al. [55], were used to predict the long-term acid generation potential of the materials. This method works by using data from kinetic tests to first construct a line representing the ratio between the cumulative-normalized mass releases of $\mathrm{Ca}+\mathrm{Mg}+\mathrm{Mn}$ and $\mathrm{S}$. The initial contents of $\mathrm{Ca}+$ $\mathrm{Mg}+\mathrm{Mn}$ vs. $\mathrm{S}$ in the bulk solid material is then plotted on the same graph. If the point representing the initial composition lies below the curve representing the leachates. the material is considered acid generating in the long-term, and vice versa. The effective reaction rate coefficient $\left(\mathrm{K}_{\mathrm{r}}\right)$ was estimated to evaluate the diffusive flux of oxygen migrating the cover materials (TG, $\mathrm{WL}$, and $\mathrm{WP}$ ) into the reactive tailings. To determine the $K_{r}$ of the TR and TG, a single-chamber oxygen consumption test (OCT) was performed [56-58]. During this test, oxygen diffusing through the tailings is consumed by sulfide minerals. A gradual decrease in $\mathrm{O}_{2}$ concentrations in the sealed headspace was recorded over 3 to $5 \mathrm{~h}$. The raw data obtained from these tests were iteratively compared with models generated using the Pollutev7 software from GAEA Technologies [59]. By fixing the effective diffusion coefficient $\left(D_{e}\right)$ based on the volumetric water content and porosity of the material in the cell. the $\mathrm{K}_{\mathrm{r}}$ could be varied until the model matched the experimental data. More details on the interpretation of OCTs using the Pollute software can be found in the literature $[57,58,60]$.

\subsection{Construction of the Laboratory Column Tests and Analyses}

Four columns ( $14 \mathrm{~cm}$ in diameter for the tailings and $30 \mathrm{~cm}$ for waste rock, $50-80 \mathrm{~cm}$ in height) were constructed in the laboratory in order to study the separate geochemical behavior of reactive tailings and cover materials (Figure 1). The top of the columns was left open to the atmosphere. The bottom boundary condition of the columns was controlled by a porous ceramic plate and a drain that maintained a hydraulic pressure equivalent to the water table, which was located approximately $1 \mathrm{~m}$ below the base of the columns. Every 28 to 30 days, $2 \mathrm{~L}$ of deionized water was added at the top of the columns. This volume represents the void volumes of the TR, which also corresponds to approximately $50 \%$ of typical monthly precipitation at the sample sites based on the average local climate [10,61,62]. A total of 19 cycles (532 days) were applied to Column 1 and 16 cycles (448 days) to Columns 2, 3, and 4 .

The effluents recovered after a maximum flush time of $24 \mathrm{~h}$ for each cycle were submitted to physicochemical analyses. The $\mathrm{pH}$ and electrical conductivity (EC) were measured using an Oakton pHTestr ${ }^{\circledR} 30$ probe (accuracy of \pm 0.01 for $\mathrm{pH}$ and $\pm 0.5 \%$ for EC) that was calibrated with standard buffer solutions at $\mathrm{pH} 4,7$, and 10 and using EC standards at 100 and $1.413 \mu \mathrm{S} / \mathrm{cm}$. The Oakton ORPTestr ${ }^{\circledR} 30$ probe was also used to determine the redox potential (Eh). Alkalinity and acidity were measured using a Metrohm 848 Titrino plus automatic titrator. Sulfate concentrations were determined with an 850 Professional IC Anion-MCS, while metal concentrations were measured by ICP-AES. The accuracy of the methods used for sulfate concentrations, metal concentrations, and alkalinity and acidity measurements was approximately $\pm 15 \%$. Samples for sulfate and metal concentration analyses were filtered to $0.45 \mu \mathrm{m}$ prior to analysis. Samples for metal concentration analyses were also acidified to $2 \% \mathrm{v} / \mathrm{v} \mathrm{HNO}_{3}$ for preservation before analysis. 


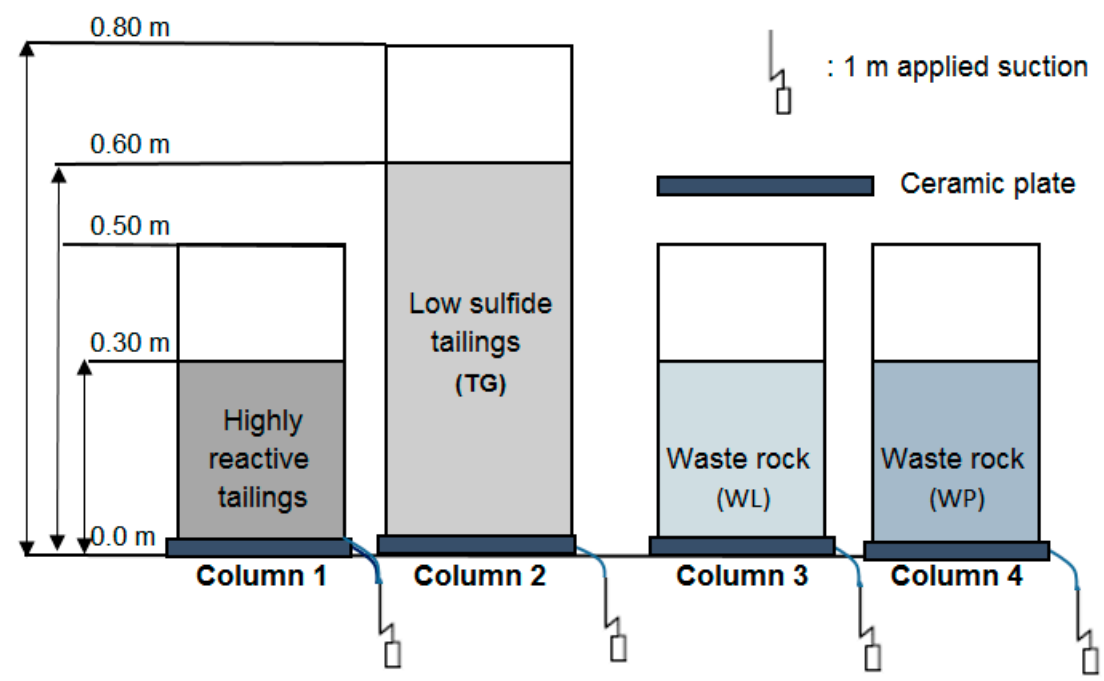

Figure 1. Experimental setup showing the columns.

\subsection{Description of the Control Field Cell and Geochemical Monitoring}

A field experimental control cell, which contained only uncovered reactive tailings, was built in early autumn 2016 at the LaRonde mine site to evaluate the influence of field conditions on the reactivity of the tailings. Results from the control column and the control cell were intended to serve as a basis for comparison with the scenarios with covers. To construct the cell, a hydraulic excavator was used to create an inverted truncated pyramid in a waste rock pad. The interior sides of the cell were sloped (2H:1V) to obtain the desired size and geometry (Figure 2a).

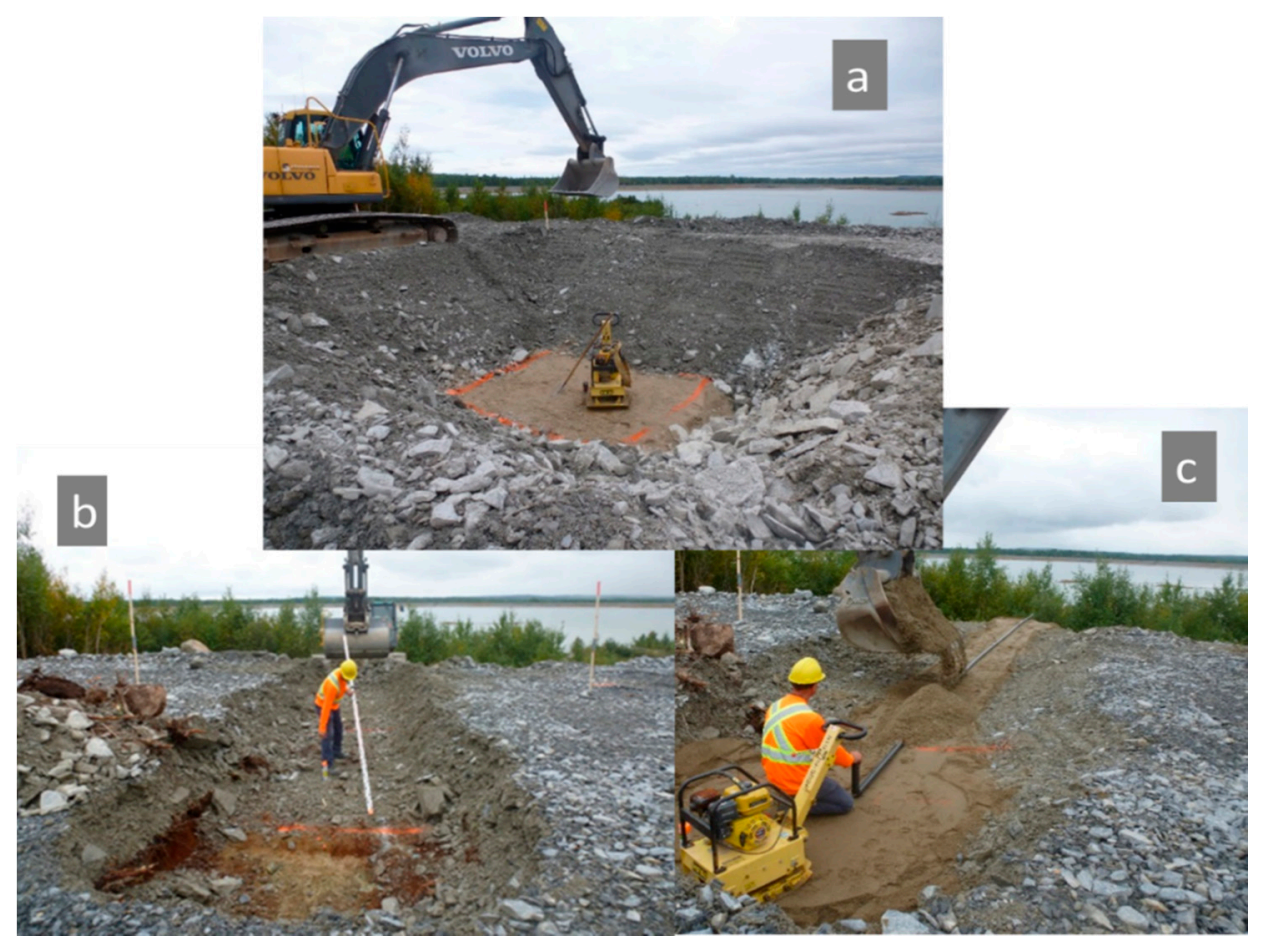

Figure 2. (a) Inverted truncated pyramid form of the experimental cell, (b) excavation of the trench, and (c) installation of the PVC pipe for the drainage water.

A trench was excavated with a slope of $1 \%$ over a distance of approximatively $16 \mathrm{~m}$ in order to create the exit for the drain (Figure 2b). A 30-cm-thick compacted fine sand layer was placed at the bottom of the trench and a 2-inch diameter PVC pipe was installed for channeling drainage waters 
(Figure 2c). The pipe was protected by another $30 \mathrm{~cm}$ of compacted fine sand on top. Sand was placed at the bottom and along the sides of the cells (Figure 3a), which were then lined with a geomembrane to control exfiltration and avoid external water contamination (Figure 3b).

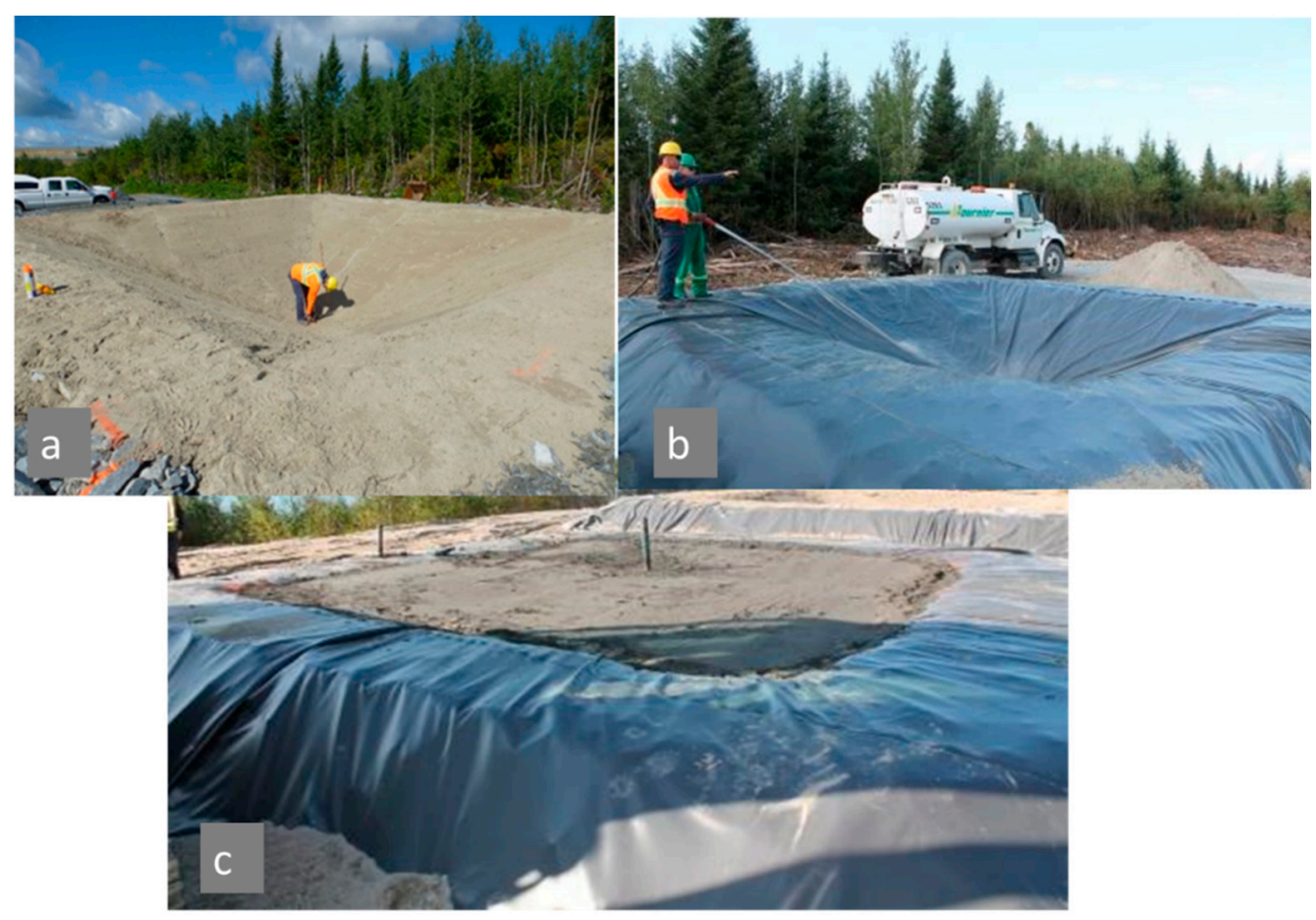

Figure 3. $(\mathbf{a}, \mathbf{b})$ sand and geomembrane installation, respectively, and (c) filling the control cell with reactive tailings.

The control cell was instrumented with sensors for volumetric water content $(\theta)$ and matric suction $(\psi)$, then filled with uncovered reactive tailings (Figures 3c and 4). 5TM sensors (version R2.04, Decagon Devices, Pullman, WA, United States) were used to monitor $\theta$ from a monitoring station that was equipped with an Em50 data logger. Suction measurements were performed using WATERMARK sensors (model 200SS, IRROMETER Company, Riverside, CA, United States). The measurement frequency was fixed at once every four hours for $\theta$, whereas $\psi$ values were measured every two weeks. The surface of the control cell was approximately $25 \mathrm{~m}^{2}(5 \mathrm{~m} \times 5 \mathrm{~m})$ (Figure 4). The top of the cell was open to natural infiltration. The drainage outlet was equipped with a sampling port and connected to a tote tank with a storage capacity of more than $1000 \mathrm{~L}$, which was used to quantify the volume of drainage water (Figure 4).

Drainage waters were collected from the control cell once every two weeks for 3 years (2017-2019) during unfrozen periods (May to October). The two biweekly samples taken each month were mixed to form a composite sample for metal and sulfate analyses. Measurements of pH, EC, Eh, acidity, and alkalinity were performed on each sample. The $\mathrm{pH}, \mathrm{Eh}$, and $\mathrm{EC}$ of the leachates were measured directly on site at the time of sampling to avoid water quality evolution during transport; all other chemical analyses were performed in the laboratory. All water samples were immediately refrigerated until analyses. 


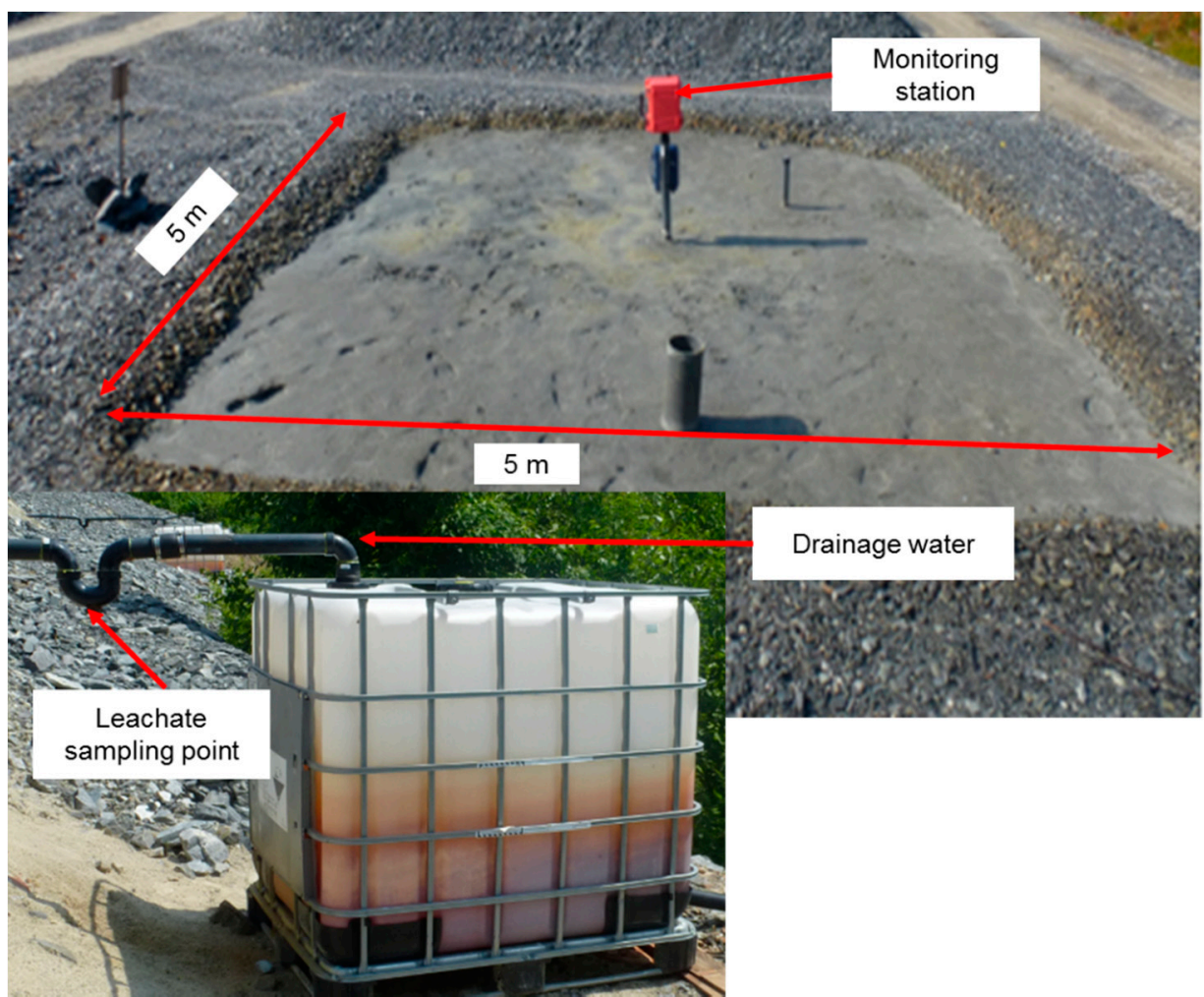

Figure 4. Picture of field experimental cell filled with uncovered reactive tailings.

\section{Results and Discussion}

\subsection{Physical, Hydrogeological, Mineralogical, and Environmental Characteristics}

The main material characterization data are presented in Tables 1-3. These data show that TG tailings are somewhat finer than the TR tailings, and that both waste rocks have similar GSDs. According to USCS classification [63]. the GSD of the tailings and waste rocks were typical of a plastic silt (ML) and well-graded sand (SW), respectively. Given the high relative density $\left(\mathrm{G}_{\mathrm{s}}\right)$ of sulfide minerals, their relative proportions in each material ( $\mathrm{TR}=24 \%, \mathrm{TG}=0.3 \%, \mathrm{WP}=1.4 \%$, and $\mathrm{WL}=0.5 \%$ ) explain the $\mathrm{G}_{\mathrm{s}}$ values $(\mathrm{TR}=3.2, \mathrm{TG}=2.7, \mathrm{WP}=2.7$, and $\mathrm{WL}=2.8)$.

Table 1. Main physical and hydrogeological properties of the materials used in this study.

\begin{tabular}{cccccc}
\hline Parameters & Units & TR & TG & WP & WL \\
\hline $\mathrm{D}_{10}$ & $\mathrm{~mm}$ & 0.009 & 0.0026 & 0.160 & 0.165 \\
$\mathrm{D}_{50}$ & $\mathrm{~mm}$ & 0.068 & 0.016 & 10 & 10 \\
$\mathrm{D}_{60}$ & $\mathrm{~mm}$ & 0.088 & 0.022 & 17 & 15 \\
$\mathrm{G}_{\mathrm{S}}$ & - & 3.22 & 2.68 & 2.72 & 2.76 \\
$\mathrm{k}_{\mathrm{sat}}$ & $\mathrm{cm} / \mathrm{s}$ & $2 \times 10^{-4}$ & $5 \times 10^{-5}$ & $3 \times 10^{-2}$ & $2 \times 10^{-2}$ \\
$\mathrm{AEV}$ & $\mathrm{m}$ of water & 2 & 2.5 & 0.002 & 0.003 \\
$\theta_{\mathrm{s}}$ & $\mathrm{m}^{3} / \mathrm{m}^{3}$ & 0.45 & 0.43 & 0.35 & 0.35 \\
$\theta_{\mathrm{r}}$ & $\mathrm{m}^{3} / \mathrm{m}^{3}$ & 0.01 & 0.06 & 0.00 & 0.00 \\
\hline
\end{tabular}

$\mathrm{D}_{\mathrm{x}}$-particle diameter corresponding to $\mathrm{x} \%$ passing in the cumulative grain-size distribution curve; $\theta_{\mathrm{s}}$-saturated volumetric water content; $\theta_{\mathrm{r}}$-residual volumetric water content; -: dimensionless quantity. 
Table 2. Mineralogical and geochemical composition of reactive tailings and cover materials.

\begin{tabular}{ccccc}
\hline Mineral Phase & Reactive Tailings (TR) & Low-Sulfide Tailings (TG) & Waste Rock (WP) & Waste Rock (WL) \\
\hline & $\% \mathrm{w} / \mathrm{w}$ & $\% \mathrm{w} / \mathrm{w}$ & $\% \mathrm{w} / \mathrm{w}$ & $\% \mathrm{w} / \mathrm{w}$ \\
Albite & $8.2 \%$ & $52 \%$ & $27 \%$ & $38 \%$ \\
Actinoline & - & $0.2 \%$ & - & $5 \%$ \\
Anhydrite & - & $0.2 \%$ & - & - \\
Calcite & - & $8.7 \%$ & - & $4 \%$ \\
Chalcopyrite & $0.9 \%$ & - & - & - \\
Chlorite & $4.4 \%$ & $13 \%$ & - & - \\
Dolomite & - & $1.2 \%$ & - & - \\
Gypsum & $1.4 \%$ & $0.7 \%$ & $3.4 \%$ & - \\
Muscovite & $1.8 \%$ & $2.8 \%$ & $1.4 \%$ & $0.5 \%$ \\
Pyrite & $24 \%$ & $0.3 \%$ & - & - \\
Pyrrhotite & $4.5 \%$ & - & $68 \%$ & $34 \%$ \\
Quartz & $53 \%$ & $22 \%$ & - & - \\
Rutile & $0.4 \%$ & - & - & - \\
Sphalerite & $2 \%$ & - &
\end{tabular}

-: Not detected.

Table 3. Environmental characteristics of reactive tailings and cover materials.

\begin{tabular}{ccccc}
\hline Environmental Parameters & Reactive Tailings (TR) & Low-Sulfide Tailings (TG) & Waste Rock (WP) & Waste Rock (WL) \\
\hline$S_{\text {total }}$ & $17 \%$ & $0.13 \%$ & $0.61 \%$ & $0.21 \%$ \\
C total $_{\text {AP }}$ & $0.03 \%$ & $0.85 \%$ & $0.14 \%$ & $0.26 \%$ \\
NP & 531 & 4 & 71 & 7 \\
NNP & 3 & 67 & -7 & 22 \\
NP/AP & -528 & 17 & 0.63 & 3.14 \\
K $_{\mathrm{r}}$ & 0.006 & $4.2 \times 10^{-6} / \mathrm{s}$ & - & -
\end{tabular}

$\mathrm{NNP}=$ net neutralization potential $(\mathrm{NNP}=\mathrm{NP}-$ acid potential $(\mathrm{AP})), \mathrm{AP}, \mathrm{NP}, \mathrm{NNP}$ in $\mathrm{kg} \mathrm{CaCO}_{3}$ eq/t and -:

not determined.

The $\mathrm{k}_{\text {sat }}$ values obtained during the permeability tests ranged from 2 to $3 \times 10^{-2} \mathrm{~cm} / \mathrm{s}$ for WL and WP, respectively, and were $2 \times 10^{-4} \mathrm{~cm} / \mathrm{s}$ for TR, and $5 \times 10^{-5} \mathrm{~cm} / \mathrm{s}$ for TG. The air entry values (AEV) obtained from the materials' WRCs, were $2 \mathrm{~m}$ and $2.5 \mathrm{~m}$ of water for TR and TG, respectively. The AEV for the waste rocks varied between $0.002 \mathrm{~m}$ and $0.003 \mathrm{~m}$ of water. These hydrogeological properties are similar to those found in the literature for other tailings [64] and waste rocks [28,30,41,47].

Mineralogical analyses identified mostly sulfide, carbonate, and silicate minerals in the different materials, with some smaller contributions from other phases (Table 2).

Sulfide minerals such as pyrite $(24 \%)$, pyrrhotite $(4.5 \%)$, sphalerite $(2 \%)$, and traces of chalcopyrite $(<1 \%)$ were identified in the reactive tailings, but no carbonate minerals were present. The silicate minerals in the reactive tailings that can neutralize at least some acid were albite $(8.2 \%)$ and chlorite $(4.4 \%)$. There is a low amount of pyrite $(<1 \%)$, high amount of carbonate (dolomite, $<2 \%$ and calcite, $9 \%)$ and silicate (albite, $52 \%)$ in the TG sample. Sulfide and silicate minerals such as pyrite $(<2 \%)$, albite $(27 \%)$, muscovite $(3 \%)$, and quartz $(68 \%)$ were identified in the WP, but no carbonate minerals were found. The WL sample contained small amounts of pyrite $(<1 \%)$, calcite $(4 \%)$, quartz $(34 \%)$, albite $(38 \%)$, and approximately $20 \%$ of other silicate minerals. Two silicate minerals (quartz and albite) represent between $70 \%$ and $95 \%$ of the mineralogy of the three cover materials. Sulfate minerals, such as gypsum, were found in both the TR (1.4\%) and TG samples $(0.7 \%)$.

To classify the acid generation potential of the tested materials. the following criteria were used: (1) $\mathrm{NP} / \mathrm{AP} \leq 1$ and/or net neutralizing potential $(\mathrm{NNP}=\mathrm{NP}-\mathrm{AP}) \leq 20 \mathrm{~kg} \mathrm{CaCO} 3 \mathrm{eq} / \mathrm{t}$ is acid generating; (2) $1<\mathrm{NP} / \mathrm{AP}<2.5$ and/or $20<\mathrm{NNP}<20 \mathrm{~kg} \mathrm{CaCO} 3$ eq/t is uncertain; and 3) NP/AP $\geq 2.5$ and/or NNP $\geq 20 \mathrm{~kg} \mathrm{CaCO} 3 \mathrm{eq} / \mathrm{t}$ is not acid generating [52,65]. Calculated values for the NNP and NP/AP of all materials are displayed in Table 3.

The TR showed an NNP of $-531 \mathrm{~kg} \mathrm{CaCO} 3 \mathrm{eq} / \mathrm{t}$ and an NP/AP ratio well below one, indicating that the material is acid-generating. The NNP of the TG sample was 67 and its NP/AP was 17, clearly indicating that the material is non-acid generating. The WP sample had an NNP of $-7 \mathrm{~kg} \mathrm{CaCO}$ 
eq/t, which is situated within the zone of uncertainty, and an NP/AP ratio below 1 , indicating that WP is potentially acid-generating. The NNP of the WL was $15 \mathrm{~kg} \mathrm{CaCO}_{3}$ eq/t, suggesting that the acid generation potential is uncertain, but its $\mathrm{NP} / \mathrm{AP}$ ratio was greater than 2.5 , meaning that the material is likely not potentially acid-generating.

Figure 5 shows the decreases in oxygen concentrations measured during the OCTs that were used to determine the effective reaction rate coefficient, $\mathrm{K}_{\mathrm{r}}$, of the tailings samples. Oxygen concentrations decreased from 20.6 to $18.2 \%$ after $3 \mathrm{~h}$ for TR (Figure 5a). Models generated using Pollutev7 predicted a decrease in oxygen concentrations of up to $18.4 \%$ after three hours for TR. In contrast to the OCT performed on TR, it took nearly $24 \mathrm{~h}$ to achieve a similar decrease (20.5 to $18.9 \%$ ) for TG (Figure $5 \mathrm{~b}$ ). The $\mathrm{K}_{\mathrm{r}}$ values were determined iteratively by varying the value until the model produced the best fit with the empirical data. The $K_{\mathrm{r}}$ values obtained for the TR and TG samples were $3.2 \times 10^{-4} \mathrm{~s}^{-1}$ and $4.2 \times 10^{-6} \mathrm{~s}^{-1}$, respectively. The $\mathrm{K}_{\mathrm{r}}$ of the TG sample is on the same order of magnitude as values obtained by [66] and [30] for desulfurized and low-sulfide tailings, respectively. For reactive tailings, [67] found values that were lower than those obtained in this study by about two orders of magnitude. There are almost no results in the literature presenting $\mathrm{K}_{\mathrm{r}}$ on materials with a similar level of reactivity to the TR sample used in this study.
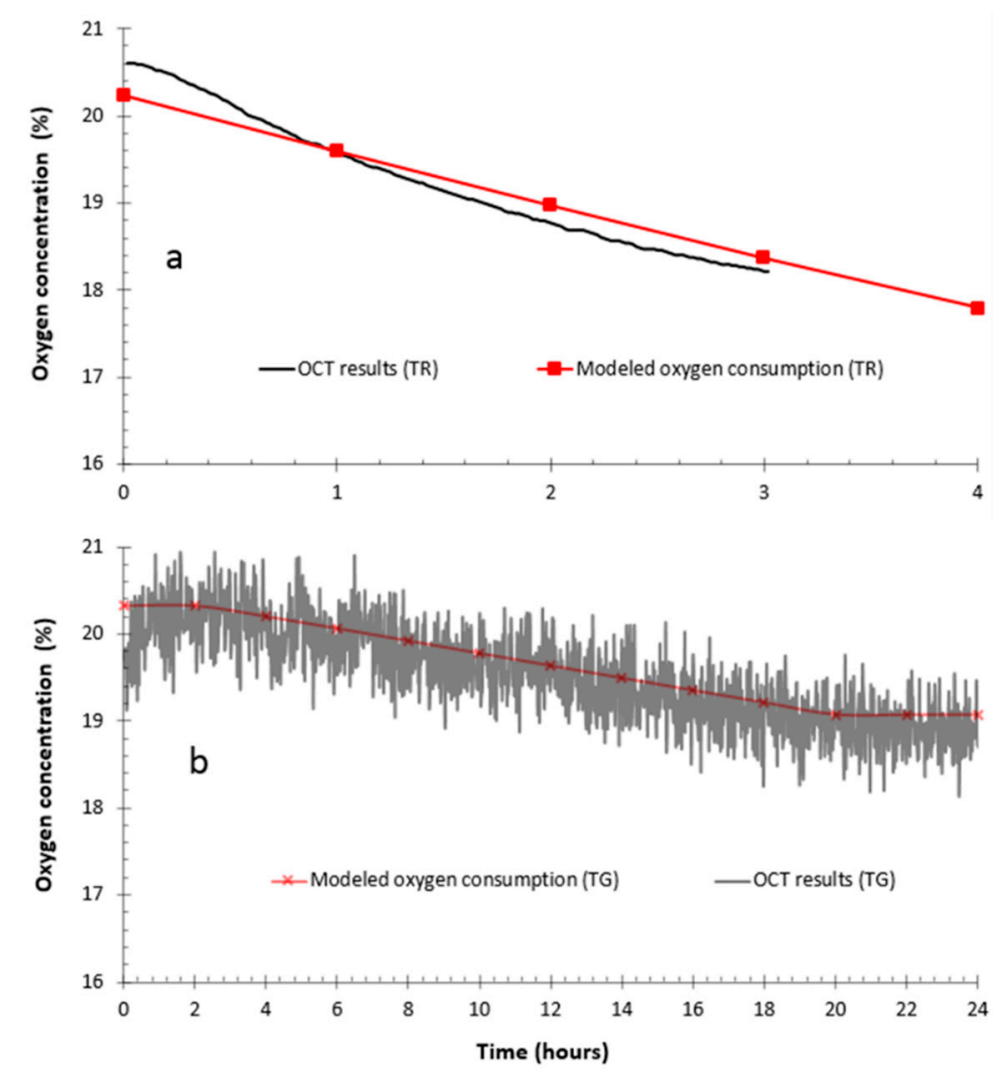

Figure 5. Temporal evolution of measured and modeled oxygen concentrations for: (a) the reactive tailings and (b) the low-sulfide tailings.

\subsection{Geochemical Behavior of the Reactive Tailings and Cover Materials}

Chemical analyses were performed on the leachates collected from the laboratory columns for each wetting cycle (Figure 6). The water quality of the field control cell was also measured. Table 4 summarizes the physicochemical results of leachates collected. 

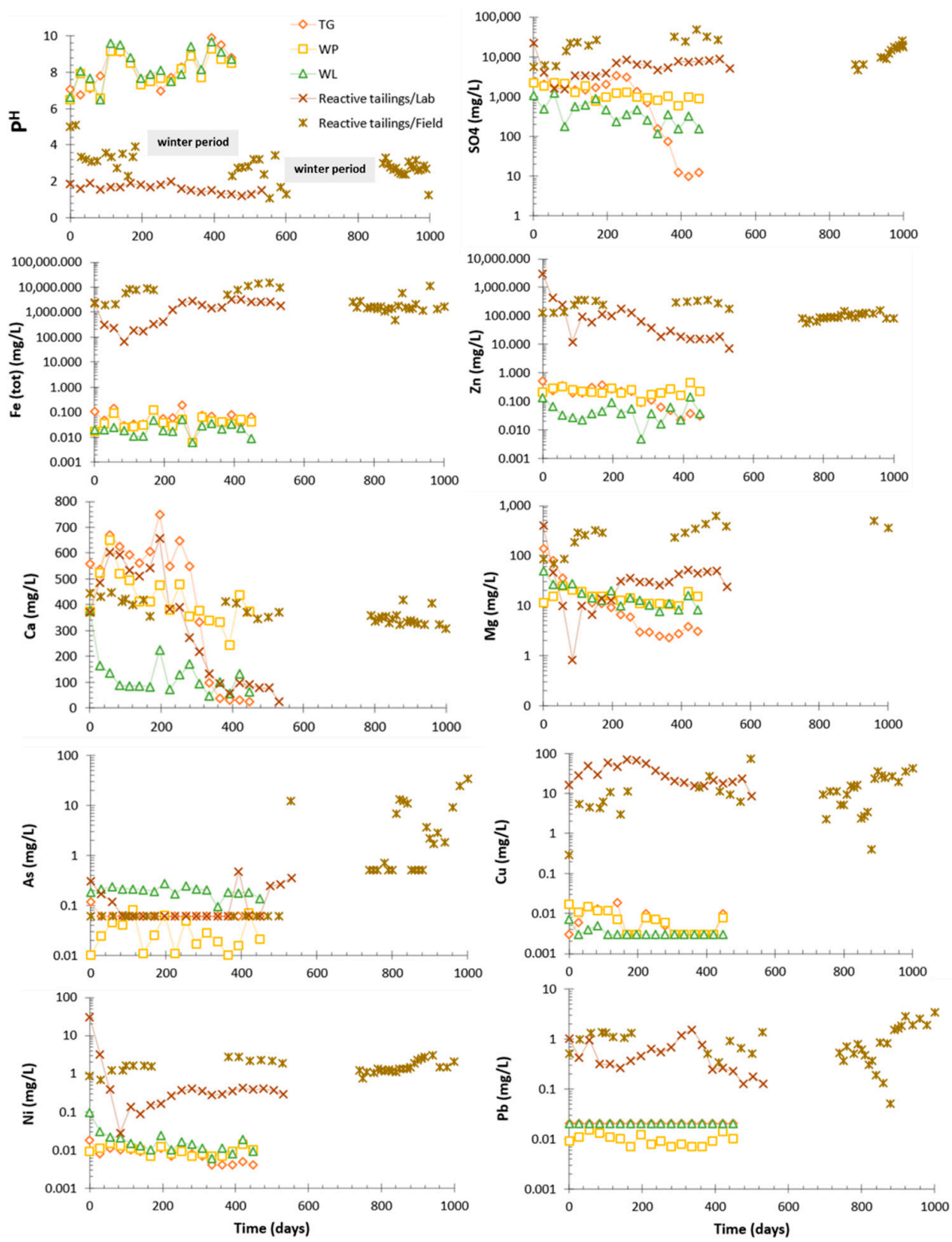

Figure 6. Water quality evolution in leachates from the reactive tailings and cover materials.

The $\mathrm{pH}$ of the leachates from the control column and field cell varied between 1.2 and 2, and 1.0 and 5 , respectively (Figure 6). The average concentrations of metals and sulfate measured in leachates from the TR were (lab/field): $\mathrm{Fe}=1560 / 4330 \mathrm{mg} / \mathrm{L}, \mathrm{Zn}=230 / 170 \mathrm{mg} / \mathrm{L}, \mathrm{Ca}=300 / 370 \mathrm{mg} / \mathrm{L}, \mathrm{Mg}=50 / 300 \mathrm{mg} / \mathrm{L}$, As $=0.14 / 4.0 \mathrm{mg} / \mathrm{L}, \mathrm{Pb}=0.5 / 7.0 \mathrm{mg} / \mathrm{L}, \mathrm{Ni}=2.0 / 2.0 \mathrm{mg} / \mathrm{L}, \mathrm{Cu}=33 / 15 \mathrm{mg} / \mathrm{L}$, and $\mathrm{SO}_{4}=6300 / 18,000 \mathrm{mg} / \mathrm{L}$. As observed. the average concentrations of $\mathrm{Fe}, \mathrm{Mg}, \mathrm{Ca}, \mathrm{As}, \mathrm{Pb}$, and $\mathrm{SO}_{4}$ were generally higher in leachates from the field. All leachates from the cover materials (TG, WP, and WL) had $\mathrm{pH}$ values between 6 and 9 throughout the duration of the column tests (Figure 6). Average concentrations of Fe and $\mathrm{Zn}$ in the leachates from the cover materials were less than $1 \mathrm{mg} / \mathrm{L}$. The average concentrations of $\mathrm{Ca}$ and $\mathrm{Mg}$ in the leachates of the cover materials were between 120 and $420 \mathrm{mg} / \mathrm{L}$, and 10 to $20 \mathrm{mg} / \mathrm{L}$, respectively. Concentrations of $\mathrm{Ni}, \mathrm{Pb}$, and $\mathrm{Cu}$ in the leachates of the cover materials were less than 0.1 , 0.02 , and $0.03 \mathrm{mg} / \mathrm{L}$, respectively (Figure 6). Concentrations of As were less than $0.1 \mathrm{mg} / \mathrm{L}$ in leachates from the TG and WP samples, and less than $0.2 \mathrm{mg} / \mathrm{L}$ in leachates from the WL sample (Figure 6). A significant decrease in sulfate concentrations, down to about $10 \mathrm{mg} / \mathrm{L}$, was observed in the TG tailings after 200 days. For the two tested waste rocks, sulfate concentrations were typically between 100 and $2000 \mathrm{mg} / \mathrm{L}$. 
Table 4. Summary of the water quality results from reactive tailings and cover materials.

\begin{tabular}{|c|c|c|c|c|c|c|c|c|c|c|c|c|c|c|c|}
\hline \multirow[t]{2}{*}{$\begin{array}{l}\text { Physicochemical } \\
\text { Parameters }\end{array}$} & \multicolumn{3}{|c|}{$\begin{array}{c}\text { Reactive Tailings (TR) } \\
\text { (Laboratory Control Column) }\end{array}$} & \multicolumn{3}{|c|}{$\begin{array}{l}\text { Reactive Tailings (TR) } \\
\text { (Field Control Cell) }\end{array}$} & \multicolumn{3}{|c|}{ Low Sulfide Tailings (TG) } & \multicolumn{2}{|c|}{ Waste Rock (WP) } & \multirow[b]{2}{*}{ Mean } & \multicolumn{3}{|c|}{ Waste Rock (WL) } \\
\hline & Min & $\operatorname{Max}$ & Mean & Min & Max & Mean & Min & Max & Mean & Min & Max & & Min & Max & Mean \\
\hline $\mathrm{pH}$ & 1.2 & 2.0 & 1.6 & 1.1 & 5.1 & 2.3 & 6.7 & 9.9 & 8.2 & 6.5 & 9.3 & 8.0 & 6.5 & 9.7 & 8.3 \\
\hline $\mathrm{Fe}(\mathrm{mg} / \mathrm{L})$ & 65 & 3210 & 1560 & 495 & 14,700 & 4325 & 0.003 & 0.192 & 0.07 & 0.003 & 0.13 & 0.04 & 0.003 & 0.05 & 0.02 \\
\hline $\mathrm{Zn}(\mathrm{mg} / \mathrm{L})$ & 7 & 2940 & 230 & 57 & 368 & 163 & 0.02 & 0.5 & 0.2 & 0.10 & 0.47 & 0.24 & 0.003 & 0.14 & 0.05 \\
\hline Sulfates $(\mathrm{mg} / \mathrm{L})$ & 1533 & 22,000 & 6300 & 4660 & 47,644 & 18,022 & 10 & 3340 & 1330 & 580 & 2250 & 1200 & 120 & 1200 & 460 \\
\hline $\mathrm{Ca}(\mathrm{mg} / \mathrm{L})$ & 23 & 660 & 300 & 307 & 447 & 369 & 26 & 750 & 420 & 250 & 650 & 420 & 50 & 400 & 120 \\
\hline $\mathrm{Mg}(\mathrm{mg} / \mathrm{L})$ & 0.8 & 400 & 50 & 69 & 621 & 298 & 3.0 & 140 & 10 & 10 & 25 & 15 & 7.0 & 50 & 20 \\
\hline As $(\mathrm{mg} / \mathrm{L})$ & 0.06 & 0.48 & 0.14 & 0.06 & 34 & 3.9 & 0.06 & 0.1 & 0.06 & 0.06 & 0.06 & 0.06 & 0.093 & 0.27 & 0.2 \\
\hline $\mathrm{Ni}(\mathrm{mg} / \mathrm{L})$ & 0.028 & 30 & 2.0 & 0.7 & 3.0 & 2.0 & 0.002 & 0.02 & 0.008 & 0.007 & 0.02 & 0.010 & 0.006 & 0.09 & 0.02 \\
\hline $\mathrm{Pb}(\mathrm{mg} / \mathrm{L})$ & 0.13 & 2.0 & 0.5 & 0.34 & 35 & 7.0 & $<$ DLM & $<$ DLM & N.D. & $<$ DLM & $<$ DLM & N.D. & $<$ DLM & $<$ DLM & N.D. \\
\hline $\mathrm{S}(\mathrm{mg} / \mathrm{L})$ & 650 & 7600 & 2100 & 0.1 & 11,900 & 5618 & 6.0 & 840 & 400 & 270 & 600 & 430 & 60 & 420 & 150 \\
\hline $\mathrm{EC}(\mathrm{mS} / \mathrm{cm})$ & 2.5 & 11 & 5 & 4.2 & 20 & 10 & 0.2 & 3.0 & 1.4 & 0.2 & 1.9 & 1.4 & 0.4 & 1.8 & 0.7 \\
\hline Alkalinity $\left(\mathrm{mg} \mathrm{CaCO}_{3} / \mathrm{L}\right)$ & $<$ DLM & $<$ DLM & N.D. & $<$ DLM & $<$ DLM & N.D. & 70 & 200 & 100 & 7.0 & 40 & 25 & 25 & 100 & 40 \\
\hline Acidity $\left(\mathrm{mg} \mathrm{CaCO}_{3} / \mathrm{L}\right)$ & 900 & 14,000 & 1500 & 447 & 34,020 & 15,864 & 0.0 & 14 & 7.0 & 0.0 & 28 & 9.0 & 0.0 & 28 & 6.0 \\
\hline Redox potential $(\mathrm{mV})$ & 500 & 700 & 600 & 349 & 575 & 509 & 360 & 580 & 470 & 370 & 570 & 520 & 380 & 580 & 500 \\
\hline
\end{tabular}

DLM: detection limit of the method; N.D.: Not determined. 
The difference between the mean Fe concentrations of the reactive tailings and the cover materials was five orders of magnitude. The high Ca concentrations (60 to $600 \mathrm{mg} / \mathrm{L}$ ) appearing in the beginning of the column tests on the TR sample (between 0 and 200 days) appeared to be related to gypsum dissolution since no carbonate minerals were detected in this material. The subsequent reduction in $\mathrm{Ca}$ concentrations was more rapid in the laboratory control column than in the field cell.

The sources of some elements measured in the leachate (especially $\mathrm{Pb}, \mathrm{Ni}$, and $\mathrm{Co}$ ), some of which are not presented here) were not able to be identified through XRD and SEM analyses. These elements are assumed to originate from impurities in sulfides [68,69].

Figure 7 presents oxidation-neutralization curves for the materials used in this study. According to this approach. the reactive tailings are categorized as acid generating (i.e.. the point representing the initial composition lies below the curve) and the TG sample and waste rocks (WL and WP) are classified as non-acid generating (i.e.. the points representing the initial compositions are above the curves).
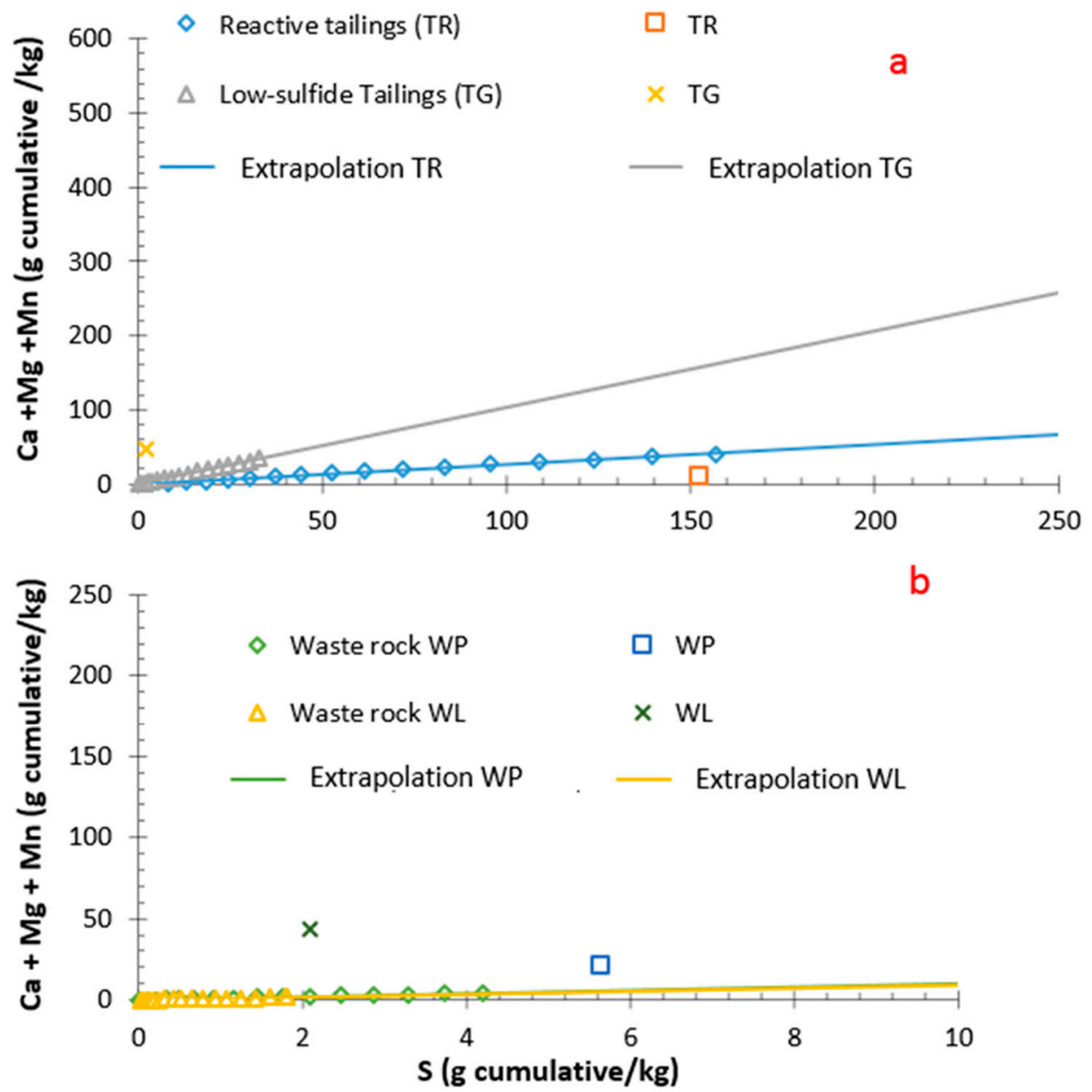

Figure 7. Oxidation-neutralization curves for the: (a) tailings and (b) waste rocks. Points represent the initial compositions of the materials.

\subsection{Selection Criteria of Materials for a Cover with Capillary Barrier Effects}

Table 5 uses data from prior studies to summarize the main selection criteria for materials to be used in the construction of a CCBE. These criteria are compared with the physical, hydrogeological, and environmental properties of the waste materials examined in the present study. 
Table 5. Criteria for choosing materials for covers with capillary barrier effects.

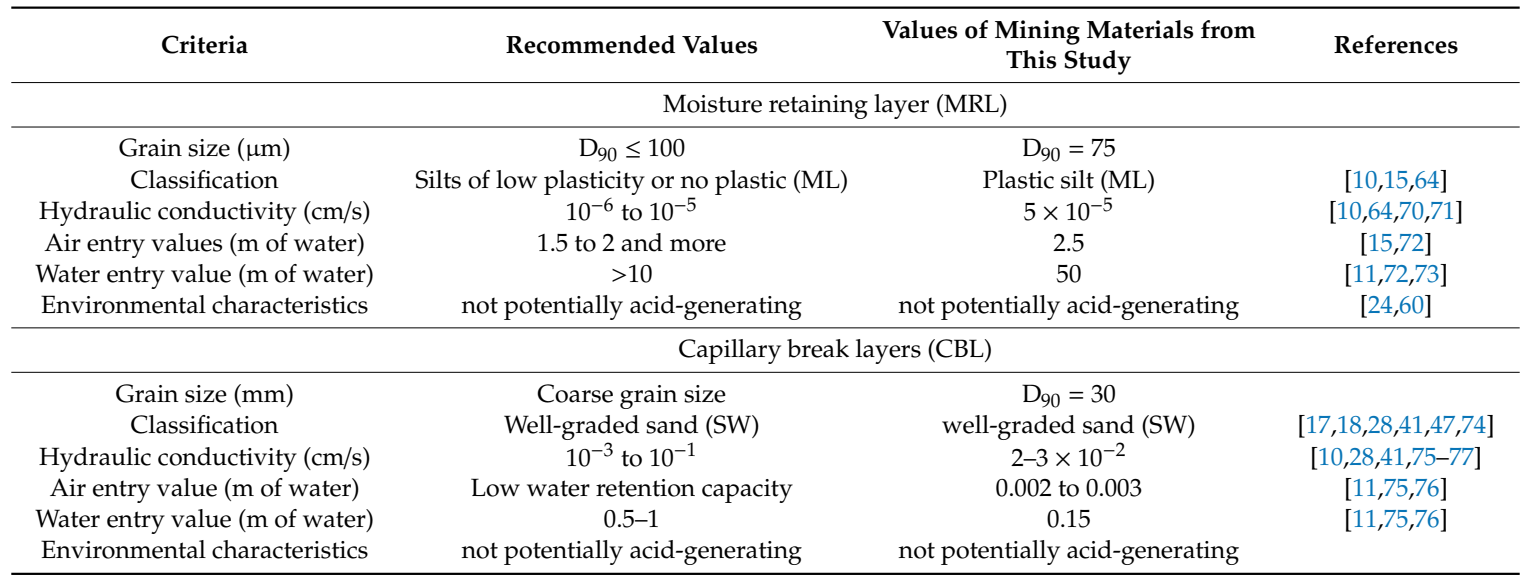

The hydrogeological properties of the materials from the present study are similar to those found in the literature for tailings [64] and waste rocks [28,30,41,47]. Values of $k_{\text {sat }}$ for the tailings and waste rock are within the range of those previously published in the literature for CCBE materials. The significant contrast between the $\mathrm{k}_{\text {sat }}$ values of the fine and coarse materials (nearly three orders of magnitude) is in accordance with the recommendations made by [10] for the development of capillary barrier effects. Moreover. the AEV of the MRL is significantly greater than the WEV of the waste rock material used as the CBL ( $2.5 \mathrm{~m}$ of water vs. $0.7 \mathrm{~m}$ of water). This means that the waste rock will reach its residual volumetric water content before the MRL starts to drain; thus, ensuring that the MRL will maintain a high degree of saturation [24]. The environmental and geochemical behavior of the cover materials presented above shows that they are not acid-generating or metal leaching, which is essential for cover materials.

\section{Conclusions}

The main objective of this research was to study the hydrogeochemical behavior of highly reactive tailings protected by a CCBE made entirely with low-reactivity mine waste materials (i.e., desulfurized tailings and waste rocks). Since all cover materials can have an influence on the hydrogeological and geochemical behavior of a cover system, experiments were first conducted in the laboratory to characterize the physical, hydrogeological, geochemical, and mineralogical properties of the reactive tailings and the cover mining materials.

In this first article in a series of two, geochemical results and the extrapolation of the kinetic tests results indicate that the reactive tailings are highly acid-generating and the cover materials (TG, WP, and WL) are not acid-generating or metal leaching. Results also showed that hydrogeological properties of the tested materials are similar to those found in the literature for tailings and waste rocks. The low-sulfide materials that were used in this study have suitable hydrogeological properties to be used as CCBE materials. More specifically. the low-sulfide tailings have a $\mathrm{k}_{\text {sat }}$ value on the order of $10^{-5} \mathrm{~cm} / \mathrm{s}$ and an AEV of $2.5 \mathrm{~m}$ of water; these values are similar to values used in the past in efficient CCBEs $[17,18,26,64,78]$. The waste rocks tested in this study have hydrogeological properties typical of those expected for the CBL of a CCBE, with a high $\mathrm{k}_{\text {sat }}$ value $\left(10^{-2} \mathrm{~cm} / \mathrm{s}\right)$ and a low water retention capacity ( $\mathrm{AEV}=0.002-0.003 \mathrm{~m}$ of water). Therefore. the tested materials have the appropriate geochemical and hydrogeological properties to be used as CCBE components.

In the second part of this study. the materials are tested in CCBE cover systems, both in the laboratory and in the field, to validate their capacity to control AMD generation from highly reactive tailings. 
Author Contributions: Conceptualization and methodology, A.K.-K., B.B., and I.-D.; formal analysis and investigation, A.K.-K.; writing-original draft preparation, A.K.-K.; writing-review and editing, A.K.-K., B.B., and I.-D.; Supervision, B.B., and I.-D. All authors have read and agreed to the published version of the manuscript.

Funding: This research was funded by Mitacs (https://www.mitacs.ca/fr, project number IT09666) and the NSERC-UQAT Industrial Research Chair on Mine Site Reclamation and its partners.

Acknowledgments: The authors would like to acknowledge the partners of UQAT-Polytechnique Research Institute on Mines and the Environment (RIME), as well as the NSERC-UQAT Industrial Chair on Mine Sites Reclamation for their financial support. The authors would like also to thank the Unité de Recherche et Service en Technologie Minérale (URSTM) staff and LaRonde environmental team for their assistance at the LaRonde mine site.

Conflicts of Interest: The authors declare no conflict of interest.

\section{References}

1. Blowes, D.W.; Ptacek, C.J.; Jambor, J.L.; Weisener, C.G. The geochemistry of acid mine drainage. In Environmental Geochemistry-Treatise on Geochemistry; Holland, H.D., Turekian, K.K., Eds.; Elsevier: Amsterdam, The Netherlands, 2003; Volume 9, pp. 149-204.

2. Rimstidt, J.D.; Vaughan, D.J. Pyrite oxidation: A stateof- the-art assessment of the reactionmechanism. Geochim. Cosmochim. Acta 2003, 67, 873-880. [CrossRef]

3. Nordstrom, D.K.; Blowes, D.W.; Ptacek, C.J. Hydrogeochemistryand microbiology of mine drainage: An update. Appl. Geochem. J. 2015, 57,3-16. [CrossRef]

4. Alphane, V.; Vermeulen, P.D. Acid mine drainage and its potential impact on the water resources in the Waterberg coalfield, South Africa. S. Afr. J. Geol. 2015, 118, 55-70. [CrossRef]

5. Nordstrom, D.K.; Alpers, C.N. Geochemistry of acid mine waters. In The Environmental Geochemistry of Mineral Deposits, Part A, Processes, Techniques, \& Health Issues. Reviews in Economic Geology; Society of Economic Geologists: Littleton, CO, USA, 1999; Volume 6A, pp. 133-160.

6. Nicholson, R.V. Overview of Near Neutral $p H$ Drainage and Its Mitigation: Results of a MEND Study; MEND Ontario Workshop: Sudbury, ON, Canada, 2004.

7. Blowes, D.; Ptacek, C.; Jambor, J.; Weisener, C.; Paktunc, D.; Gould, W.; Johnson, D. The geochemistry of acid mine drainage. In Treatise on Geochemistry; Elsevier: Amsterdam, The Netherlands, 2014.

8. Lindsay, M.B.J.; Moncur, M.C.; Bain, J.G.; Jambor, J.L.; Ptacek, C.J.; Blowes, D.W. Geochemical and mineralogical aspects of sulfide mine tailings. Appl. Geochem. J. 2015, 57, 157-177. [CrossRef]

9. SRK. Draft Acid Rock Drainage. Technical Guide Vol. 1, British Columbia Acid Mine Drainage Task Force Report, Prepared by Steffen, Robertson, Kirsten in Association with Norecol Environmental Consultants and Gormely Process Engineering; Ministry of Energy Mines and Petroleum Resources: Vancouver, BC, Canada, 1989.

10. Aubertin, M.; Chapuis, R.P.; Aachib, M.; Bussière, B.; Ricard, J.F.; Tremblay, L. Evaluation en Laboratoire de Barrières Sèches Construites à Partir de Résidus Miniers; Rapport NEDEM/MEND Projet 2.22.2a; Ecole Polytechnique de Montréal: Ottawa, ON, Canada, 1995.

11. Nicholson, R.V.; Gillham, R.W.; Cherry, J.A.; Reardon, E.J. Reduction of acid generation in mine tailings through the use of moisture-retaining layers as oxygen barriers. Can. Geotech. J. 1989, 26, 1-8. [CrossRef]

12. Morel-Seytoux, H.J. L'effet de barrière capillaire à l'interface de deux couches de sol aux propriétés fort contrastées. Hydrol. Cont. 1992, 7, 117-128.

13. Hotton, G.; Bussière, B.; Pabst, T.; Bresson, E.; Roy, P. Influence of climate change on the ability of cover with capillary barrier effects to control acid generation. Hydrogeol. J. 2019, 28, 763-779. [CrossRef]

14. Yanful, E.K. Development of Laboratory Methodology for Evaluating the Effectiveness of Reactive Tailings Covers; Final Report (Draft); Centre de Technologie Noranda: Pointe-Claire, QC, Canada, 1991.

15. Bussière, B.; Aubertin, M.; Chapuis, R.P. The behaviour of inclined covers used as oxygen barriers. Can. Geotech. J. 2003, 40, 512-535. [CrossRef]

16. Aubertin, M.; Bussière, B.; Pabst, T.; James, M.; Mbonimpa, M. Review of reclamation techniques for acid generating mine wastes upon closure of disposal sites. Paper Presented at the Geo-Chicago, Sustainability, Energy and the Geoenvironment, Chicago, IL, USA, 14-18 August 2016.

17. Ricard, J.F.; Aubertin, M.; Firlotte, F.W.; Knapp, R.; McMullen, J. Design and construction of a dry cover made of tailings for the closure of Les Terrains Aurifères site. In Proceedings of the 4th International Conference on Acid Rock Drainage, Vancouver, BC, Canada, 31 May-6 June 1997; Volume 4, pp. 1515-1530. 
18. Ricard, J.F.; Aubertin, M.; Garand, P. Performance d'un recouvrement multicouche au site Barrick-Bousquet de Les Terrains Aurifères. In Proceedings of the 20th Symposium on Wastewater; Delisle, C.E., Bouchard, M.A., Eds.; Collection Environnement de l'Université de Montréal: Montréal, QC, Canada, 1997; Volume 10, pp. 291-305.

19. Bussière, B.; Aubertin, M.; Benzaazoua, M.; Gagnon, D. Modèle d'estimation des coûts de restauration de sites miniers générateurs de DMA. In Proceedings of the Mines Écologiques, Congrès APGGQ, Rouyn-Noranda, QC, Canada, 5 August 1999.

20. Gee, G.W.; Benson, C.H.; Albright, W.H. Comment on "evaluation of evapotranspiration covers for waste containment in arid and semiarid regions in the southwestem USA". Vadose Zone J. 2006, 5, 809-812. [CrossRef]

21. Gorakhi, M.H.; Bareither, C.A. Sustainable reuse of mine tailings and waste rock as water-balance covers. Minerals 2017, 7, 128. [CrossRef]

22. Tardif-Drolet, M.; Li, L.; Pabst, T.; Zagury, G.J.; Mermillod-Blondin, R.; Genty, T. Revue de la réglementation sur la valorisation des résidus miniers hors site au Québec. Canadian science publishing. Doss. Environ. 2019. [CrossRef]

23. Aachib, M.; Aubertin, M.; Chapuis, R.P. Essais en colonne sur des couvertures avec effets de barrière capillaire. In Proceedings of the 51st Canadian Geotechnical Conference, Canadian Geotechnical Society, Edmonton, AB, Canada, 4-7 October 1998; Volume 2, pp. 837-844.

24. Bussière, B.; Benzaazoua, M.; Aubertin, M.; Mbonimpa, M. A laboratory study of covers made of low sulphide tailings to prevent acid mine drainage. Environ. Geol. 2004, 45, 609-622. [CrossRef]

25. Aubertin, M.; Bussière, B.; Barbera, J.M.; Chapuis, R.P.; Monzon, M.; Aachib, M. Construction and instrumentation of in situ test plots to evaluate covers built with clean tailings. In Proceedings of the 4th International Conference on Acid Rock Drainage (ICARD), Vancouver, BC, Canada, 31 May-6 June 1997; Volume 2, pp. 715-730.

26. Bussière, B.; Maqsoud, A.; Aubertin, M.; Matschuk, J.; Mcmullen, J.; Julien, M. Performance of the oxygen limiting cover at the LTA site, Malartic, Québec. CIM Bull. 2006, 1, 1-11.

27. Pabst, T.; Bussière, B.; Aubertin, M.; Molson, J. Comparative performance of cover systems to prevent acid mine drainage from pre-oxidized tailings: A numerical hydro geochemical assessment. J. Contam. Hydrol. 2018, 214, 39-53. [CrossRef] [PubMed]

28. Kalonji-Kabambi, A.; Bussière, B.; Demers, I. Hydrogeological Behaviour of cover with Capillary Barrier Effect made of Mining Materials. Geotech. Geol. Eng. J. 2017, 35, 1199-1220. [CrossRef]

29. Maqsoud, A.; Bussière, B.; Turcotte, S.; Roy, M. Performance evaluation of covers with capillary barrier effects under deep groundwater conditions using experimental cells. In Proceedings of the Géo Ottawa Conference, Ottawa, ON, Canada, 1-4 October 2017; p. 256.

30. Larochelle, C.G. Utilisation de Stériles Générateurs D'acide Comme Couche de Bris Capillaire Dans Une Couverture Avec Effet de Barrière Capillaire. Master's Thesis, Université du Québec en Abitibi-Témiscarningue, Rouyn-Noranda, QC, Canada, 2019.

31. Yanful, E.K.; Verma, A.; Straatman, A.S. Turbulence driven metal release from suspended pyrrhotite tailings. J. Geotech. Geoenviron. Eng. 2000, 126, 1157-1165. [CrossRef]

32. Davé, N.K.; Paktunc, A.D. Surface reactivity of high-sulfide copper mine tailings under shallow water cover conditions. In Proceedings of the 6th ICARD, Cairns, Queensland, Australia, 14-17 July 2003; pp. 241-251.

33. Awoh, A.S.; Mbonimpa, M.; Bussière, B.; Plante, B.; Hassan Bouzahzah, H. Laboratory study of highly pyritic tailings submerged beneath a water cover under various hydrodynamic conditions. Mine Water Environ. 2014, 33, 241-255. [CrossRef]

34. Awoh, A.S.; Mbonimpa, M.; Bussière, B. Field study of the chemical and physical stability of highly sulphide-rich tailings stored under a shallow water cover. Mine Water Environ. 2013, 32, 42-55. [CrossRef]

35. Kalonji-Kabambi, A. Étude du Comportement Hydrogéologique D’une Couverture Avec Effets de Barrière Capillaire Faite Des Matériaux Miniers à L'aide de Modélisations Physique et Numérique. Master's Thesis, École Polytechnique de Montréal, Montréal, QC, Canada, 2014.

36. Kalonji-Kabambi, A.; Demers, I.; Bussière, B. Numerical modeling of covers with capillary barrier effects made entirely of mining materials. In Proceedings of the Tailings and Mines Waste Conference, Keystone, CO, USA, 2-5 October 2016. 
37. Lee Black, D.; McQuay, M.Q.; Bonin, M.P. Laser-based techniques for particle-size measurement: A review of sizing methods and their industrial applications. Prog. Energy Combust. Sci. 1996, 22, 267-306. [CrossRef]

38. ASTM. D422. Standard Test Method for Particle-Size Analysis of Soils; American Society for Testing and Materials (ASTM): West Conshohocken, PA, USA, 2007.

39. ASTM. D854-10. Standard Test Methods for Specific Gravity of Soil Solids by Water Pycnometer. In ASTM Annual CDs of Standards; American Society for Testing and Materials (ASTM): West Conshohocken, PA, USA, 2012.

40. ASTM. D5856-07. Standard Test Method for Measurement of Hydraulic Conductivity of Porous Materials Using Rigid-Wall, Compaction-Mold Permeameter; American Society for Testing and Materials (ASTM): West Conshohocken, PA, USA, 2007.

41. Peregoedova, A.; Aubertin, M.; Bussière, B. Laboratory measurement and prediction of the saturated hydraulic conductivity of mine waste rock. In Proceedings of the GeoMontréal Conference, Montréal, QC, Canada, 29 September-3 October 2013; p. 165.

42. ASTM. Reapproved D3152-72. Standard Test Method for Capillary-Moisture Relationships for Fine-Textured Soils by Pressure-Membrane; 2 Annual Book of ASTM Standards (Reapproved 2000); 100 Barr Harbor Drive: West Conshohocken, PA, USA, March 1972; Volume 4.

43. Van Genuchten, M.; Leij, F.J.; Yates, S.R. The RETC Code for Quantifying Hydraulic Functions of Unsaturated Soils; Environmental Protection Agency: Cincinnati, OH, USA, 1991; EPA/600/2-91/065.

44. Van Genuchten, M. A Closed-form equation for predicting the hydraulic conductivity of unsaturated soils. Soil Sci. Soc. Am. 1980, 44, 892-898. [CrossRef]

45. Chapuis, R.; Masse, I.; Madinier, B.; Aubertin, M. A drainage column test for determining unsaturated properties of coarse materials. Geotech. Test. J. 2006, 30, 83-89.

46. Hernandez, A.M. Une Étude Expérimentale Des Propriétés Hydriques Des Roches Stériles et Autres Matériaux à Grannulométrie Étalée. Master's Thesis, École Polytechnique de Montréal, Montréal, QC, Canada, 2007.

47. Peregoedova, A.; Aubertin, M.; Bussière, B. Evaluation of the water retention curve of mine waste rock using laboratory tests and predictive models. In Proceedings of the GeoRegina Conference, Regina, SK, Canada, 28 September-1 October 2014; p. 247.

48. Rietveld, H.M. The Rietveld Method; Young, R.A., Ed.; Oxford University Press: Oxford, UK, 1993; Chapter 2.

49. Taylor, J.C.; Hinczak, I. Rietveld Made Easy: A Practical Guide to the Understanding of the Method and Successful Phase Quantifications; University of Wollongong: Wollongong NSW, Australia, 2001.

50. Bouzahzah, H. Modification et Amélioration Des Tests Statiques et Cinétiques Pour Une Prédiction Fiable du Drainage Minier Acide. Ph.D. Thesis, Université du Québec en Abitibi-Témiscamingue, Rouyn-Noranda, QC, Canada, 2013.

51. Petruk, W. The MP-SEM-IPS image analysis system. In CANMET Report 87-1E (CANMET, Dept Energy, Mines, and Resources; Canada Department of Energy, Mines and Resources: Ottawa, ON, Canada, 1986.

52. Miller, S.D.; Jeffery, J.J.; Wong, J.W.C. Use and misuse of the Acid-Base account for AMD prediction. Paper Presented at the 2nd International Conference, Abatement of Acidic Drainage, Montreal, QC, Canada, 16-18 September 1991; Volume 3, pp. 489-506.

53. Morin, K.A.; Hutt, N.M. Environmental Geochemistry of Minesite Drainage: Practical Theory and Case Studies; MDAG Pub.: Vancouver, BC, Canada, 2001.

54. Mine Environment Neutral Drainage (MEND). Report 1.20.1 Prediction Manual for Drainage Chemistry from Sulphidic Geologic Materials; CANMET-Mining and Minerals Sciences Laboratories: Smithers, BC, Canada, 2009.

55. Benzaazoua, M.; Bussière, B.; Dagenais, A.M.; Archambault, M. Kinetic tests comparison and interpretation for prediction of the Joutel tailings acid generation potential. Environ. Geol. 2004, 46, 1086-1101. [CrossRef]

56. Mbonimpa, M.; Aubertin, M.; Aachib, M.; Bussière, B. Diffusion and consumption of oxygen in unsaturated cover materials. Can. Geotech. J. 2003, 40, 916-932. [CrossRef]

57. Gosselin, M.; Mbonimpa, M.; Aubertin, M.; Martin, V. An investigation of the effect of the degree of saturation on the oxygen reaction rate coefficient of sulphidic tailings. In Proceedings of the ICAST'07, Accra, Ghana, 10-12 December 2007.

58. Ouangrawa, M.; Aubertin, M.; Molson, J.W.; Bussière, B.; Zagury, G.J. Preventing acid mine drainage with an elevated water table: Long-Term Column Experiments and parameter analysis. Water Air Soil Pollut. 2010, 213, 437-458. [CrossRef]

59. Rowe, R.K.; Booker, J.R. Pollutev7 Reference Guide; GAEA Technologies Ltd.: Greater Napanee, ON, Canada, 2004. 
60. Demers, I.; Bussière, B.; Mbonimpa, M.; Benzaazoua, M. Oxygen diffusion and consumption in low-sulphide tailings covers. Can. Geotech. J. 2009, 46, 454-469. [CrossRef]

61. Aachib, M. Étude en Laboratoire de la Performance de Barrières de Recouvrement Constituées de Rejets Miniers Pour Limiter le DMA. Ph.D. Thesis, École Polytechnique de Montréal, Montréal, QC, Canada, 1997.

62. Dagenais, A.M. Techniques de Contrôle du Drainage Minier Acide Basées Sur Les Effets Capillaires. Ph.D. Thesis, École Polytechnique de Montréal, Montréal, QC, Canada, 2005.

63. McCarthy, D.F. Essentials of Soil Mechanics and Foundations: Basic Geotechnics; Pearson Prentice Hall: Upper Saddle River, NJ, USA, 2007.

64. Bussière, B. Colloquium 2004: Hydrogeotechnical properties of hard rock tailings from metal mines and emerging geoenvironmental disposal approaches. Can. Geotech. J. 2007, 44, 1019-1052. [CrossRef]

65. Sobek, A.A.; Schuller, W.A.; Freeman, J.R.; et Smith, R.M. Field and Laboratory Methods Applicable to Overburdens and Mine Soil; EPA Report No. EPA-600/2-78-054; Environmental Protection Agency: Cincinnaty, OH, USA, 1978; pp. 47-50.

66. Lessard, F. Évaluation de Couverture Isolantes Avec Effets de Barrière Capillaire Faites de Résidus Désulfurés Afin de Contrôler le Drainage Minier en Conditions Nordiques. Master's Thesis, Université du Québec en Abitibi-Témiscarningue, Rouyn-Noranda, QC, Canada, 2018.

67. Nyameogo, G. Développement D'un Système de Mesure et D'un Modèle Théorique Préliminaire D'estimation du Coefficient de Diffusion de L'oxygène Dans Les Matériaux Poreux Inertes Gelés. Master's Thesis, Université du Québec en Abitibi-Témiscamingue, Rouyn-Noranda, QC, Canada, 2017.

68. Vaughan, D.J. Sulfide Mineralogy and Geochemistry. In Reviews in Mineralogy and Geochemistry; Mineralogical Society of America: Chantilly, VA, USA, 2006; Volume 61, p. 714.

69. Vaughan David, J.; Corkhill Claire, L. Mineralogy of sulfides. Elements 2017, 13, 81-87. [CrossRef]

70. Aubertin, M.; Chapuis, R.P. Critères de conception pour les ouvrages de retenue des résidus miniers dans la région de l'Abitibi. In Proceedings of the 1ère Conférence Canadienne de Géotechnique Environnementale, Montréal, QC, Canada, 14-16 May 1991; pp. 113-127.

71. Pabst, T. Etude Expérimentale et Numérique du Comportement Hydro-Geochimique de Recouvrement Placé Sur Des Résidus Sulfureux Partiellement Oxydés. Ph.D. Thesis, École Polytechnique de Montréal, Montréal, QC, Canada, 2011.

72. Mine Environment Neutral Drainage (MEND). Étude de Laboratoire Sur le Recouvrement Construits Avec Des Résidus Miners; MEND 2.22.2c; Canada Centre for Mineral and Energy Technology (CANMET): Ottawa, ON, Canada, 1999.

73. Aubertin, M.; Chapuis, R.P.; Bussière, B.; Aachib, M. Propriétés des résidus miniers utilisés comme matériau de recouvrement pour limiter le DMA. In Symposium International Géologie et Confinement des Déchets Toxiques, Géoconfine'93, Arnould; Barrès, M., Côme, B., Eds.; Balkema: Rotterdam, The Netherlands, 1993; pp. 299-308.

74. Bussière, B.; Aubertin, M.; Julien, M. Couvertures avec effets de barrière capillaire pour limiter le drainage minier acide, aspects théoriques et pratiques. Vecteur Environ. 2001, 34, 37-50.

75. Morin, K.A.; Gerencher, E.; Jones, C.E.; Konasewich, D.E. Critical literature review of acid drainage from waste rock. In Canadian Mine Environmental Neutral Drainage (MEND) Program; Canada Centre for Mineral and Energy Technology: Ottawa, ON, Canada, 1991.

76. Aubertin, M.; Bussière, B.; Bernier, L. Environnement et Gestion des Rejets Miniers; Presses Polytechnique Int.: Montréal, QC, Canada, 2002.

77. Mine Environment Neutral Drainage (MEND). Étude en Laboratoire de Barrière Seches Construites à Partir de Résidus Miners; MEND 2.22.2a; Canada Centre for Mineral and Energy Technology (CANMET): Ottawa, ON, Canada, 1996.

78. Bussière, B.; Potvin, R.; Dagenais, A.M.; Aubertin, M.; Maqsoud, A.; Cyr, J. Restauration du site minier Lorraine, Latulipe, Québec: Résultats de 10 ans de suivi. Déchets Revue Francophone d'écologie Industrielle 2009, 2, 54. [CrossRef]

(C) 2020 by the authors. Licensee MDPI, Basel, Switzerland. This article is an open access article distributed under the terms and conditions of the Creative Commons Attribution (CC BY) license (http://creativecommons.org/licenses/by/4.0/). 